\title{
Celebrity Endorsement Influence on Brand Credibility: A Critical Review of Previous
}

\section{Studies}

\author{
Okorie Nelson, Covenant University, Nigeria \\ Agbaleke Deborah, Covenant University, Nigeria
}

\begin{abstract}
Celebrity endorsement is a potent adverting strategy used to promote brands in the market space. In Africa and Asia, celebrity endorsement has developed dramatically as an essential promotional approach used by advertisers to influence consumers about their brands. The trust of this paper examines the nature and dimensions of celebrity endorsement influence on consumers. Furthermore, the locus of the paper critically examines the review of previous studies on celebrity endorsement influence on brand credibility. The paper concludes that the use of celebrity endorsement in the eyes of customers is the most compelling way of attracting their attention compared to a non-celebrity featured advertisement.
\end{abstract}

Keywords: Celebrity, endorsement, advertising, brand and credibility 


\section{Introduction}

In retrospect, the concept of using celebrities to endorse various brands was at its lowest ebb in many African and Asian countries such as Nigeria, because many companies lack the willingness to spend their money and majority of them had low or no competitors to compete with (Okorie, Oyedepo \& Akhedenor, 2011; Okorie, 2013; Zafar \& Rafique, 2014). But recently, the global market has grown tougher each passing year with different companies rendering services to the same market audience. Companies now engage in various marketing communication strategies in a bid to steal the larger share of the market from their competitors which includes; the use of celebrities to gain their audience attention and patronage. Studies agree that celebrity endorsements are effective in getting attention and associating a brand with a certain personality can entice consumers (Okorie, 2010; Okorie \& Aderogba, 2011; Okorie, Oyedepo\& Akhedenor, 2011; Okorie, 2013; Omotayo, 2014; Zafar $\&$ Rafique, 2014).

Most organizations and companies are now more interested in marketing their products and gaining a lot of market shares. Also, these companies focus in satisfying their consumer's needs and maintaining their loyalty. Despite the cost and risk involved with this technique of advertising with celebrities, it has been use quite extensively in this present era to influence audience patronage. Advertisers go to the extent of endorsing countless celebrities to present an image of perfection in the minds of the audience than going after the credibility of the company in order to gain the people's trust and patronage. This paper examines celebrity endorsement influence on brand credibility based on previous qualitative and quantitative studies.

\section{Celebrity Endorsement and Advertising}

Celebrity endorsement refers to a claim by a celebrity or someone of authority that a product is good thereby certifying such product as a must have. Celebrity endorsement as defined by Okafor (2011) is a technique of persuasion where customers relate to person used or featured in an advert. Celebrity endorsement is most effectively utilised by companies when the endorser's personality matches up to that of the brand or product. As suggested by Friedman and Friedman, a "celebrity endorser is an individual known by public for their area of achievement than the product class"; this makes most advertisers accent to the idea that the 
use of celebrity endorsement cannot only create a great deal of awareness, it can also positively affect consumers making them feel safe about their brand or product.

Celebrity endorsement is a technique that is adopted in advertising campaign; this is used to boost and give a product an added advantage to a brand because when celebrity endorsers appear in an ad campaign, consumers tend to feel a sense of belonging to the brand in question. However, advertising campaigns usually take longer than a normal advertisement that can take up-to 2 minutes. Advertising campaigns that make use of celebrity endorsers tend to have an increased profit and increased customer base. Belch and Belch (2012) mentioned that consumers are more easily influenced by a message that comes from a person with whom they can relate with or feel close to. As opposed to the feeling of belonging, celebrities also need to be admired by these consumers, a celebrity endorser that is admired by its target market/audience is bound to attract more than enough profit for the company. Celebrities are good at creating attention, recall and awareness. Roozen and Claeys (2010, p. 4) argue that every product has an image; the use of celebrity endorsement brings the image of the product closer to the expectations of the consumer, by transferring some of the cultural meanings residing in his image of the product.

\section{Dimensions of Celebrity Endorsement}

Celebrities are famous and well-known people. People whose actions and opinions strongly influence the course of events in the society, their status is often associated with fame and wealth that can often provide opportunities to make money. People may also become celebrities due to media attention for their lifestyle, wealth, actions or for their connection to a famous person. As stated by Khatri (2006, p. 26), celebrities are people who enjoy public recognition by a large share of certain group of people. They act as spokes people for a brand in advertising; to promote products and services. According to (Piyush, 2012), a firm that decides to employ a celebrity has a choice of using the celebrity as; (a) TESTIMONIAL: This is when the celebrity has personally used the product or service and is in a position to confirm its quality. (b) ENDORSEMENT: In this technique, celebrities offer their names to ads for products or services which they may or may not have any slim idea about the product. (c) ACTOR: A celebrity may be asked to present a product as part of character enactment rather than personal testimonial. This might appear in a movie or a public place or environment. (d) SPOKESPERSON: In this aspect, celebrity who represents a brand or company over an 
extended period of time often in any media outlet or personal appearance is usually called a company's spokesperson.

There are two forms of celebrities in advertising: Celebrity license and Celebrity endorsement (Piyush, 2012). He explained that celebrity license is not used often, as it tends to be a longterm, co-branding commitment by both the corporation and the celebrity as the celebrity adds his/her likeness or name directly to a product. The essence of this relationship is that the celebrity and the product are directly associated with each other; this can either be a strength or a weakness depending on the status of the celebrity and the quality of the product.

Celebrity endorsements are the widely used strategy of using celebrities as a promotional tool. It can have celebrities giving expert opinions, being a spokesperson for a product or just being associated with the product or service they are endorsed for.

Rojek (2014) tinted three types of celebrities which are Ascribed, Achieved and Attributed.

(a) ASCRIBED: These types of celebrity are famous because of the lineage they came from. Which includes; Royalty, socialites with long background of affluent relative and people whose parents are celebrities. (b) ACHIEVED: Achieved celebrities are people who became famous because of their talent and skill in their particular field. These are generally actors and actresses, musical artists, and sports stars. Often, achieved celebrities gain fame and recognition through, receiving a well-known award (Rojek 2014). (c) ATTRIBUTED: Attributed celebrities are those who become famous by attracting a lot of media attention or by being associated with multiple celebrities. They are seen as people who are famous simply for being famous.

One important reason why celebrities have been used for product endorsement is that the celebrity appealadds fame, talent, credibility and charisma to the product being advertised (Agrawal 2014). He assumed that celebrity appeals are costlier than any other type of appeals and has more credibility. Celebrities who are credible worldwide have been used by advertisers to endorse and market their products. While charisma of celebrity endorsers' influence the buying choice of product users optimistically, manufacturers and sellers have constantly favored to employ celebrity support to sell their goods and services (Erdogan, 1999; Kamins, 1990). He also stated that showing a celebrity in a product is for the target group to associate the product with the endorser. Celebrity appeals gain immediate attention 
and add attraction to advertisement, so a consumer can easily be attracted to a celebrity adverts. Markers have to prove the quality of the brand being advertised so they can enjoy long-term benefit from their consumers. Salespersons use celebrity support to facilitate improved storage of information in consumer's mentality which can be simply considered in buying condition (Schultz and Brens, 1995). McCracken (1998) proposes that superstars are considered like memorial, entertainer or representative of the business organization. His research has established that celebrity endorsement influence consumers' mind-set and it may change the feelings of consumers towards the commercial and products as well.

Deutsch and Gerard (1955) distinguished two kinds of social impact celebrities might sway on individuals. The first, named informational societal impact which refers to persuasion, to acknowledge the information acquired from another as indication of authenticity. The second, normative social impact refers to the influence to match another individual or group of people. Goldsmith et al., (2000) advocate that the advertisers usually use endorsers as persuasive basis to influence customers' feelings and buying objectives. Different studies indicate that celebrity credibility is positively associated with the mind-set of consumers toward an advert. Consequently, it is assumed that advertisements using credible celebrities will achieve more positive attitude towards the advertisement than the advertisements using less credible celebrities (Aziz, Ghani, \& Niazi, 2013 p.109). Lafferty and Goldsmith (1999) furthermore signify that the correlation of celebrity credibility attitude to a brand is reconciled by approach to the advert, meaning the credible personality of an endorser is linked with that of the product by adverts. When a celebrity is credible, it actually enhances the reputation of the whole corporation. Celebrity credibility is measured through three dimensions which include Trustworthiness, attractiveness and expertise (Miller \& Baseheart 1969). (A) TRUSTWORTHINESS: Miller and Baseheart (1969), States that trustworthiness is the spectator's extent of assurance and intensity of the identification of the spokesperson as well as the communication. According to (Ohanian 1991; Pornpitakpan 2003), trustworthiness is measured through not dependable or dependable, dishonest/honest, unreliable/reliable, insincere/sincere, and untrustworthy/trustworthy. It has to do with the degree of confidence in the endorser and the level of acceptance of both the speaker and the message he/she is trying to communicate. (B) EXPERTISE: The scale of measurement for expertise includes not expert or expert, inexperienced/experienced, unknowledgeable/knowledgeable, unqualified/qualified, and unskilled/skilled. When the 
source is perceived expert it has a positive impact on attitude change of the consumers (Okorie, 2010; Okorie \& Aderogba, 2011; Okorie, Oyedepo\& Akhedenor, 2011; Okorie, 2013; Omotayo, 2014). (C) ATTRACTIVENESS: The attractiveness measurement scale consists of the semantic differentials of unattractive/attractive, not classy/classy, ugly/beautiful or handsome, plain/elegant, and not sexy/sexy (Ohanian 1991; Pornpitakpan 2003; Okorie, 2010; Okorie \& Aderogba, 2011).

\section{Review of Previous Studies}

Phang and Cyril (2002) explored the issues of company image by assessing the reactions of respondents to advertising utilizing a celebrity endorser against one that does not. One out of four advertising message features celebrities in a day. The use of these celebrities in advertisements has been rapidly increasing, as it is believed to contribute substantial positive impact on financial returns for the companies that use them. These celebrities are used by companies because they believe that adverts delivered by a celebrity provides a greater degree of appeal, attention, recall and possibly purchase compared to those without celebrities. Celebrity advertisement appeal carries on towards both male and female, or only towards a particular gender and with the help of both brand ambassadors and the company's credibility playing a very significant role in the attitude of the consumers towards the advertisement and brand recall.

The findings of the research were concluded on from the results of the responses of 50 respondents, the findings show the different attitudes of consumers towards the companies' use of celebrities. The findings also identify measures of effectiveness of celebrity endorsers which includes the credibility, attractiveness, value, expertise, image etc.

In addition, Roozen and Claeys (2010) analysed the effect of celebrity endorsement on brands and products advertised; it is significant to take into account the involvement effect. The physical attractiveness of a celebrity influences the attitude change process, because they exude sexuality and increase stimulation which affects positively the processing of information. Information adopting attractiveness is better communicated faster than other information's. They categorize into low involvement and high involvement products based on the risk consumer's associate with products during purchase. 
The research shows that the sorting of a products source credibility and source attractiveness can influence a celebrity endorsers effectiveness as well as the match between the brand and product with the celebrity. Based on the analysis gotten from the research, they suggest that products that don't make use of celebrity endorsers are effective in the cognitive area of the product. This means that consumers who view these adverts and see the products in the market are rational with the product, they evaluate its value, quality, strength, benefits and cost before they make purchase. Also, the results suggest that a poorly matched-up celebrity endorser and brand is least effective in an advert.

In addition, Singh (2010) contended that there is a need to create large brand awareness and brand recall which has been a challenge for telecom industries. In choosing a celebrity as a brand ambassador, a company must be sure to choose one that portrays the image of the company. The personality of an ambassador matter a great deal to its consumers, therefore, Credibility for a brand ambassador will go farther than boost a company's growth; this therefore implies that companies should consider their reputation and that of the celebrity.

Also, Singh (2010, p. 7) suggests that a brand is a company's most valuable asset therefore, and promotion through brand ambassadors enhances its value or equity which can be leveraged by brand extension. Properly endorsed brands with well associated personality are a prominent feature that creates instant awareness and transfers goodwill to a brand. The study focusing on consumer's perception goes beyond the benefits gotten from celebrity endorsement in the telecommunication industry. The study concludes with its findings that show that consumers believe that brand ambassadors promote brand or products sales, communicate a company's new offer to consumers, define a brands personality, create interest in the product from consumers, and give a product or brand a distinctive identity.

In affirmation, Farhati and Khan (2011) measured celebrity endorsement by assuming the cognitive theory in studying the similarity between brand or product personality and celebrity personality. Hawkins et al., argues that a good matchup between celebrity and product image receives high effectiveness in adverts as cited by Farhati and Khan (2011). They examine the effectiveness of endorser and its dependent factor on the meaning the celebrity contributes to the endorsement physical process. 
The study focuses on the importance of the existence of harmony between a celebrity and a brands personality or attitude. The study tests 120 respondents with the questionnaire method, and the results of its findings reveal that the success of a brand or product promotion when assisted by the personality of both the brand or product and the celebrity is most effective. In other words, it is important to make use of celebrity brand ambassador and harmony effect as a basis for building a successful brand or product.

Giving a counterpoint, Lane, King and Reichert (2011, p. 509) indicated that an advert that features a celebrity holding a brand or product does not make the advert believable or nearly as effective as an advert that makes use of celebrity actually using such product or brand. Celebrity's personality may not be believable in most adverts, but they are effective at attracting attention which is the first step to introducing a brand or product to affect purchase. The attractiveness of the celebrity can strike decision or attention of a consumer in the place of purchase.

In a similar study, Nyakado (2011) explored celebrity endorsement and consumers tendency to be attracted to adverts that make use of their favourite celebrities. Individuals may feel more attached and compelled to products when they are related to their popular celebrities. The physical attractiveness of these celebrity endorsers influences their attitudes and decisions. Their values and credibility influences the perception of audience as well. The credibility of a celebrity endorser plays a rather significant role in influencing consumer's perception and building a strong brand for the company.

The research adopted the theories of celebrity match, celebrity attractiveness, and celebrity credibility. The researcher tests a total of 100 consumers and the findings revealed that consumers are more interested in products that are endorsed by celebrities and therefore make it a duty to be more inclined about the product. The study also revealed that products that associate with a celebrity's beauty are taken by consumers to mean that the product is of high quality. Younger consumers like teenagers are mostly influenced by attractive celebrities because they are looking for inspirational role models they want to follow and emulate. The study showed that consumer attitude is a key factor in selecting celebrity brand ambassadors or endorsers, this implies that the values of a celebrity should measure up to that of the consumer to effect a change of attitudes, celebrity endorsements are useful for marketing 
effectiveness and attracting new consumers to a brand that hold no interest for the consumer. The research concluded that celebrity credibility and attractiveness plays a significant role in influencing consumer perception, a brands outstanding identity and strong brand building for a company.

In another study, Bejaoui, Fawzi and Taoufic (2012), gave a general view of the effectiveness of the use of endorsement by celebrities by emphases on the benefits drawn from the use of celebrities in advertising. Messages sent by these celebrity brand ambassadors are more effective than that of ordinary people. Simply put, celebrities tend to draw more attention to adverts they feature as well as the brand or product it promotes. (Bejaoui, Fawzi and Taoufic, 2012, p. 4). Celebrity use strengthens a company's image and gives it an edge over its competitors. The research which conducts its test on a sample of 200 comes up with findings that aid its research they include:

1. High harmony between a brand and celebrity encourages a positive attitude toward the brand, therefore, and this contributes to communicating a message about the brand or product in a clearer sense.

2. The pairing of a brand and celebrity with similar attributes results in a positive attitude toward the brand from the consumer. The impact of consumers attitudes toward the brand, familiarity with the brand and a high involvement in the product category are major determinant factors in consumer influence from a brand or product Bejaoui, Fawzi and Taoufic (2012, p. 4).

In a similar study, Ogunsiji (2012) investigated the impact of celebrity endorsement on strategic brand management as it establishes a link between a successful celebrity brand ambassador and the power of the brand in the market. In other words, the power of a brand doesn't depend or lie in the total power of a celebrity endorser; it is dependent in the mind of its customers; their views, thoughts and reactions of the brand. Ogunsiji (2012, p. 3) views celebrity endorsement or brand ambassadors as a communication medium in brand communication where the celebrity is seen as the spokesperson.

As in the case of testimonial, the person giving his or her experience of the product is testifying on behalf of the brand or product and the testifier's testimony if believed is looked up to for prove of his or her testimony. In the same vain, the brand ambassador of a brand or 
product seen as a spokesperson gives the brand a good review thereby communicating to the consumers the excellence of the brand or product. In other words the celebrity certifies the brand's claims by extending his or her personality or status to the brand.

McCracken suggested that the existence of a symbolic match between the image of the endorser and the brand is effectual in advertising campaigns. There must also occur merging of company's interest where its perception of the celebrity matches with that of the audience perception of the celebrity and its image of the brand. The study found out that the power of a brand in the market is an increasing function of the effectieneness of the endorsement process, which improves the growth of the brand amongst its competitors.

Prasad (2012) examined on the impact of celebrities as brand ambassadors towards customer satisfaction, in the study, Prasad views it important for companies to match both the values of the celebrity with that of the brand or product, he bases his reason on the fact that consumers perceive such brands endorsed by credible celebrities or sources as having a high quality compared to other brands. In examining the effect of celebrity endorser on consumer behaviour in adverts and ad campaigns, Prasad (2012) adopts various techniques, literature and previous works to determine impact of celebrity brand ambassadors towards customer satisfaction. The research examines first four areas of literature, two in economics and the remaining two in marketing in achieving results on the study.

The study examines from the economies perspective, the concept of variable quality and its use in product differentiation and related literature on the functions of advertising as an information bank to consumers. Focusing on the marketing perspective, the study researches into the effect of adverts on the behaviour of consumers and the relative effects generated by these celebrity endorsers and brand ambassadors in advertising and ad campaigns.

The researcher links the platform for effectiveness of celebrity brand ambassador adverts to Kelman's processes of social influence as discussed by Friedman and Friedman, sited by Prasad (2012, p. 2) these processes which include Compliance, Identification and Internalization focus on adopting attitude as proponent by the source. 
Compliance: this means that an individual can influence another person or individual in the hope to achieve a favourable reaction from the individual. This process however is does not directly apply to a celebrity featured advert because there is hardly any interaction between the consumer and the celebrity.

Identification: here the individual mimics the conduct or attitude of another individual mainly because they view them as a role model and motivate to be like them. This process is the main basis for referent power, celebrities are most likely to be preferred than ordinary individuals.

Internalization: social influence occurs when individuals adopt the attitude or behaviour of another person because such behaviour is seen as honest, and in line with their value system (Prasad, 2012, p. 6).

The researcher ascertained findings include:

1. Consumers perceive a celebrity endorsed brand as of a higher quality thereby giving it a positive view.

2. The brand or product creates a special place in consumers mind when their celebrities or products are viewed in high quality

In the same vain, Goutam (2013), states that companies who invest huge sums of money in to hiring the right celebrity that matches their brand, more or less perceive these adverts or campaigns as more effective, this is because consumers see these endorsed brands as superior and of the best quality because they are endorsed by celebrities. Compared to other brands or product in such category these brands are seen as the best and in vogue. Celebrity brand ambassadors and endorsers open up new opportunities for a brand as well as the company. Goutam (p. 4) argues that since companies have begun understanding that celebrities can catalyse brand acceptance and provide the enormous momentum that brands require. But with much hype being made in celebrity endorsement and celebrity brand ambassadors, brand investment becomes a wonder. Because companies no longer bother to raise their brands standards in terms of innovation, brainstorming for better ways and ideas to make it better and leave the creation of brand recall and awareness to the endorsers and brand ambassadors. Celebrity endorsers if effectively used can establish brand recall and brand awareness but it is the duty of the company to make the brand worth the quality and high recommendation brought in by these endorsers. 
Goutam (p. 1) focuses on whether consumers choose a brand or purchase a product because it is endorsed by their favourite celebrity, the researcher tested a100 respondents and the following findings were from the result gotten:

1. Consumers would watch an advert if their favourite celebrity, personality, icon or model is featured in it

2. Consumers will most likely look at the quality or value of brand or product before they consider the celebrity being used. This implies that companies should not depend solely on celebrity endorsers to boost the credibility of their brand; endorsers are more effective when they add to brands credibility.

3. Celebrity brand ambassadors and endorsers create good brand recall and awareness through adverts or campaign.

In another study, Piyush (2013, p. 5) in his research on celebrity endorsement and brand building in India focuses on the interaction between the celebrity endorser and the product in trying to bring its image closer to consumer's expectation thereby boosting sales and brand awareness and building. By trying to bring the image of the product closer, the consumer gets the feeling of similarity to the celebrity endorser which can enforce consumption of the brand by target consumer. Piyush (2013, p. 19) argues that the best endorsement is achieved by getting a balance between the brand or product and the celebrity. In seeking a balance between the celebrity, brand or product, the company should base the selection of its celebrity on characteristics such as: the celebrities appeal, likeability, attractiveness, popularity and similarity.

The role of a celebrity in brand or product promotion/building is the most explicit and can be analysed by the using the multiplier effect formula for a successful brand or product.

S- Successful Brand, E- Effective Brand, D- Distinctive Identity, AV- Added Value (Piyush 2013, p.21). the multiplier effect formula has given by Piyush (2013, p. 21), explains further the effect/impact a celebrity has on a brand or product success; a celebrities features or characteristics adds to a brand or product image, a brand that is not effective, unsuccessful, has no effective identity or distinctive identity cannot be given an added value by a celebrity despite the effective quality of the celebrity. In other words a celebrity can only improve or impact a brand or product to an extent but without the brand or product matching up to the celebrity's image, its effect or impact is weak and less effective. 
Piyush in his research of celebrity endorsement on brand building adopts the use of descriptive studies to ascertain an accurate analysis of the situation. The method of data collection adopted by the researcher was the questionnaire method with a sample frame of 50 consumers. There are several factors that affect the success of celebrity use in brand building such as the celebrity selection based on similarity, likability, appeal and attractiveness of the celebrity. Piyush $(2013$, p. 78) as a result of this research the following findings are highlighted:

1. The level of impact of celebrity brand ambassadors on product are relatively dependent on the product or brand category

2. Celebrities appeal, popularity, attractiveness, familiarity and similarity are characteristically important basis in studying celebrity brand ambassadors or celebrity endorsement on brands

3. A consumer looks for similarity between a brand, celebrity and how it matches him/her as a consumer

In a similar study, Sharma and Kumar (2013), reasoned that celebrities who appear in adverts endorsing a brand or product can only improve the product to an extent, this means that before a brand is endorsed by a powerful celebrity, such brand or product must possess its own distinctive attribute or identity; companies make use of celebrities, whose personalities can impact their brand or product but for this to be successful, there has to exist a relationship or similarity between the celebrity and the brand or product to be endorsed. Celebrity brand ambassadors also impact an advertising campaign, because these celebrities create attention, recall and this makes more companies adopt the use of celebrities because not only do they create recall they also make use of their popularity in increasing sales and customer base of a product or brand.

There are many reasons why companies make use of celebrity as brand ambassadors, Sharma and Kumar (2013, p. 76) give two major reasons:

1. Their high profile: the high profile of celebrities as advertising campaign and adverts distinctive compared to their opponents, this distinctive quality improves the communicative ability of the brand towards its customers; because customers view them as understanding good observers because they are able to portray what their 
customers are going through if they provide them an answer and by making use of the perfect celebrity customers see themselves as having same qualities as the celebrity.

2. Celebrities create an extensive public relations influence for brands or products: using the right plan and strategy, celebrities are able to justify marketers or companies high cost of advertising (Alonso 2006, p. 76) this they do by effectively bringing out the best in the brand or product they endorse and also creating awareness for the brand or product. Celebrities who have no effective link between the message to be passed across and the brand cannot make the advert or advertising campaign successful any more than the brand is. In most cases, influence celebrities with enough stopping power are selected compared to non-celebrities.

Sharma and Kumar (2013), following an assessment of the current market concluded that celebrity brand ambassadors adopted by companies and the use of right planning if used efficiently i.e. matching the strengths of the brand and product and that of the celebrity's quality justifies the high cost related with this type of advertising. Advertising however does not alone guarantee sales of a product but when customers and celebrity brand ambassadors are in perfect agreement, it can lead to brand loyalty and a good sales promotion of the brand.

Giving a similar view, Iqbal et al., $(2014,99)$ suggested that the use of celebrity endorsement or celebrity brand ambassador in communicating the message about the features of a brand is most effective. Matching a celebrity and the brand or product to be endorsed increases the products effectiveness. Advertising can be used as a strong media of communication by which consumers are made aware of the features, attributes and benefits of the product or brand they wish to purchase. A celebrity can make pass across such message effectively if the celebrity's personality compliments that of the brand or product. Companies influence the thinking and reasoning process of consumers by making use of these celebrities, and this goes to the extent of blocking their reasoning faculty, because they see a celebrity they love making use of a product they want to get the product to feel a sense of similarity to the celebrity they love as well as feel a sense of belonging and familiarity.

In a similar study, Omotayo $(2014$, p. 3$)$ in his study on celebrity endorsements and product performance, citing Ericsson and Hakansson (2005) argues that repeated association of a brand with a particular celebrity might lead to consumers association of the brands possession 
of similar celebrity attractive qualities, which will bring about consumer purchase of the brand. belch and Belch (2001), gives celebrity stopping power as a good reason why celebrity brand ambassadors enhance ad messages and this influences consumers purchase decision as cited by Omotayo (2014, p. 3).

The research which studies 216 consumers, gives the following findings:

1. Attractiveness of a celebrity is essential in selecting a celebrity for a brand or product

2. Multiple endorsements by celebrities affect celebrity's credibility of a brand or product.

In another study, Singh (2014) argues that companies with a unique positioning of their brands or products in the minds of their target audience do this to promote sales and promote sales faster by endorsing celebrities to position their products or brands distinctively in the minds of their customers. These celebrities evoke a closer consumer connection and engagement which drives the force of purchases. In other words, companies understand the importance of using brand ambassadors in selling and promoting their brands and products to consumers, these brand ambassadors are looked up to by a certain percentage of their target audience as role models and by using a consumers role model to promote a brand or product, these consumers are drawn or attracted to the product being sold by their role model.

Singh (2014, p. 3) highlights the obvious benefits that are derived from celebrity endorsement and brand ambassadors by exploring the perception of people. The brand of a company is its most valuable asset and in promoting it through a brand ambassador, will enhance its brand value. A brand however must also have its one personality or image; a brand ambassador can do little or nothing for an empty brand with no image, distinctive feature or an identity of its own. Many companies have recognised the importance of hiring a brand ambassador that can transfer credibility, attractiveness and values to a brand, because they improve awareness of a brand by defining its personality and informing customers about the new innovations or products being offered by the brand, they add value to the brand by promoting sales. Celebrities however increase value compared to non-celebrities or ordinary individuals.

\section{Conclusion}

It is a known fact that companies and organisations make use of advertising for awareness and patronage of their products or service. Advertising is engaged in most companies for 
higher sales and patronage. The adoption and use of celebrities in advertising has in most cases raised the awareness of adverts and advertising campaign of these companies and organisations products and services and thereby increasing sales.

For most companies the utilization of celebrities as endorsers may not only increase their patronage but also affect their credibility positively. Celebrity endorsement positively affects the credibility of a brand and while quality is needed, the effectiveness of sales and patronage can be based on the quality of a brand or product and the right selection of celebrity endorsers. Celebrity endorsement has become an effective way of attracting customers and from this paper, the use of celebrity endorsement in the eyes of customers is the most compelling way of attracting their attention compared to a non-celebrity featured advertisement. 


\section{References}

Aamir, K.K, Naveed, A., Iqbal, N., Farooq, O. and Iqbal, J. (2014). Role of celebrity Endorsement upon consumer vanity with mediating role of materialism: Evidence From business students of Pakistan. Journal of business and management research. $4,98-107$

Banyte, J, Egle, S. and Piligrimiene, Z. (2011). Selecting celebrities in advertising: The case Lithuanian sports celebrity in non-sport product advertisement. Journal of Economics and management, 16, 1822-6515

Bejaoui, A, Dekhil, F. and Djemel, T. (2012). Endorsement by celebrities: The role of Congruence. Herald journal of marketing and business management, 1 (2)

Belch and Belch (2012). Advertising and promotion: An integrated marketing Communications perspective $\left(5^{\text {th }}\right.$ ed.). New York: McGraw Hill Irwin

Farhati, R. and Khan M.B. (2011). Celebrity endorsement: A congruity measure of Personalities. Research on humanities and social sciences, 1 (1)

Goutam, D. (2013). Influence of brand ambassadors on buying behaviour of soft drinks: With Reference to Belgaum City. International journal of research in business Management, 1 (4)

Johansson, J. and Sparedel, J. (2002). Celebrity endorsements: A case study of Axa and the Ludmila Engquist incident. Lulea University of technology, (1404-5508)

Kiran, S. and Kumar, S.S (2013). Celebrity endorsement in advertising; Can it lead to Brand Loyalty in The Long Run? International Journal of Marketing, Financial Services and Management Research, 2, (3)

Nyakado, J.O. (2013). Investigating celebrity endorsement in relations to consumer Behaviour (A survey of Rexona deodorant of Unilever Kenya). Journal of business Administration, (13-70)

Ogunsiji, A.S. (2012). The impact of celebrity endorsement on strategic brand management. International journal of business and social science, 2 (6)

Okorie, N. (2010). Celebrity advertising and its effect on brand loyalty. Interdisciplinary Journal of contemporary research in business, 1(4), 70-88

Okorie, N., Oyedepo T., and Akhidenor G. (2011). The Dysfunctional and Functional Effect of

Celebrity advertising. Online Journal of Communication and Technology, 2(2), 141152 
Okorie, N., and Aderogba, A. (2011). The role of celebrity advertising on brand patronage. International Journal of Research in Computer Application and Management, $1(1), 27-34$.

Okorie, N. (2013). Multiple uses of celebrities in brand promotion: An experimental investigation. Romanian Journal of Journalism and Communication, Romania, 2(39), $51-59$

Omotayo O. (2014). Celebrity endorsements and product performance: A study of Nigerian Consumer markets. Journal of marketing and management, xii (1)

Piyush R. (2012). Celebrity endorsements and brand building. Journal of advertising, (1-88)

Phang, G. and Cyril, E. (2014).Celebrity endorser and respondents gender: It's impact on Company, behavioural and attitudinal variables. Journal of economics and business, $6(1-15)$

Prasad, J. (2012). Brand endorsement by celebrities impacts towards customer satisfaction. African journal of business management, 7 (3630-3635)

Prasad, J. and Prakash, J. (2013). Brand endorsement by "Celebrities impacts towards Customer satisfaction. African journal of business management. 7 (35)

Roozen, I. and Claeys, C. (2010). The relative effectiveness of celebrity endorsement for Print advertisement. Journal of business and economics, 1 (2-14)

Singh, A. (2014). Brand ambassadors endorsing brands: A case study of Telecom companies In India. Journal of commerce, (2-11)

Zafar, Q and Rafique, M. (2014). Impact of celebrity advertisement on customers' brand Perception and purchase intention. Asian journal of business and management Sciences, 1 (11) 